\title{
Beyond Empires
}

Global, Self-Organizing, Cross-Imperial Networks,

1500-1800

\author{
Edited by
}

Cátia Antunes

Amélia Polónia

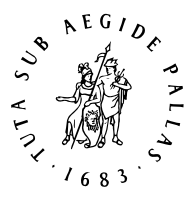

B R I L L

LEIDEN | BOSTON

For use by the Author only | (C) 2016 Koninklijke Brill NV 


\section{Contents}

General Editor's Foreword VII

List of Figures and Tables $\mathrm{X}$

List of Contributors XII

Introduction 1

Cátia Antunes and Amélia Polónia

1 The Evolution of Norms in Trade and Financial Networks in the First Global Age: The Case of the Simon Ruiz's Network 12 Ana Sofia Ribeiro

2 Trans-Imperial and Cross-Cultural Networks for the Slave Trade, 1580s-180os 41

Filipa Ribeiro da Silva

3 Dutch and English Approaches to Cross-Cultural Trade in Mughal India and the Problem of Trust, $1600-1630 \quad 69$

Guido van Meersbergen

4 'The Japanese Connection': Self-Organized Smuggling Networks in Nagasaki circa 1666-1742 88

Jurre Knoest

5 The Pirate Round: Globalized Sea Robbery and Self-Organizing Trans-Maritime Networks around $1700 \quad 138$

Michael Kempe

6 Merchant Cooperation in Society and State: A Case Study in the Hispanic Monarchy 160

Ana Crespo Solana

7 In the Shadow of the Companies: Empires of Trade in the Orient and Informal Entrepreneurship 188

Chris Nierstrasz

8 Smuggling for Survival: Self-Organized, Cross-Imperial Colony Building in Essequibo and Demerara, 1746-1796 212

Bram Hoonhout 
9 Trading with Asia without a Colonial Empire in Asia: Swedish Merchant Networks and Chartered Company Trade, 176o-179o 236 Leos Müller

10 Was Warfare Necessary for the Functioning of Eighteenth-Century Colonial Systems? Some Reflections on the Necessity of CrossImperial and Foreign Trade in the French Case 253 Silvia Marzagalli

\author{
Epilogue 278 \\ Cátia Antunes and Amélia Polónia
}

Bibliography $\quad 281$

Index 300 


\title{
Trans-Imperial and Cross-Cultural Networks for the Slave Trade, $15805-1800$ s
}

\author{
Filipa Ribeiro da Silva
}

\section{Introduction}

Most of the historiography on European engagement in the hideous transatlantic slave trade has focused primarily on the volume of voyages, slaves and African commodities. ${ }^{1}$ Until now scholars who examine merchants' participation in this trade have centred their attention mainly on the activities of state monopolies and state-sponsored commercial companies such as the Dutch West India Company (WIC), among others. ${ }^{2}$ However, according to the

1 Philip D. Curtin, The Transatlantic Slave Trade: a Census. Madison: University of Wisconsin Press, 1969. David Eltis, "The volume and structure of the Transatlantic slave trade: A reassement". The William and Mary Quarterly 58, no. 1 (2001): 17-46. David Eltis et al., The TransAtlantic Slave Trade, CD-Rом. Cambridge: Cambridge University Press, 1999. David Eltis and David Richardson (eds.), Routes to Slavery: Directions, Ethnicity, and Mortality in the Transatlantic Slave Trade. London: Frank Cass, 1997. David Eltis and David Richardson, "A New Assessment of the Transatlantic Slave Trade". In Extending the Frontiers: Essays on the New Transatlantic Slave Trade Database. Edited by David Eltis and David Richardson. New Haven: Yale University Press, 2008: 1-6o. Herbert S. Klein, The Middle Passage: Comparative Studies in the Atlantic Slave Trade. Princeton: Princeton University Press, 1978.

2 David Eltis, Stephen Behrendt, and David Richardson, "National Participation in the Transatlantic Slave Trade: New Evidence". In Africa and the Americas: Interconnections during the Slave Trade. Edited by José C. Curto and Renée Soulodre-La France. Trenton, New Jersey: Africa World Press Inc., 2005: 13-42. Jelmer Vos, David Eltis and David Richardson, "The Dutch in the Atlantic World: Perspective from the Slave Trade with particular Reference to the African origins of the Traffic". In Extending the Frontiers: 228-249. Piet C. Emmer, "The West India Company, 1621-1791: Dutch or Atlantic". In Companies and trade: essays on overseas trading companies during the Ancien Regime. Edited by Leonard Blussé and Femme Gaastra. Leiden: Leiden University Press, 1981: 71-95. Henk den Heijer, De geschiedenis van de WIC. Zupten: Walburg Pers, 1994: Chapters 1-3. Ernest van den Boogaart and P.C. Emmer, "The Dutch participation in the Atlantic Slave Trade, 1596-1650". In The Uncommon Market: Essays in the Economic History of the Atlantic Slave Trade. Edited by Henry A. Gemery and Jan S. Hogendorn. New York, N.Y.: Academic Press, 1979: 353-375. Johannes Postma, The Dutch in the Atlantic Slave Trade, 1600-1815. Cambridge: Cambridge University Press, 1990: Chapter 1. Johannes Postma, "A Reassessment of the Dutch Atlantic Slave Trade". In Riches from Atlantic Trade: Dutch Transatlantic Trade and Shipping, 1585-1817. Edited by Victor Enthoven and Johannes Postma. Leiden: Brill, 2003: 158-138.

(C) KONINKLIJKE BRILL NV, LEIDEN, 2016 | DOI 10.1163/9789004304154_004 
evidence gathered in the Transatlantic Slave Trade Database (TSTD) on vessels' owners, state-sponsored companies' participation in the transatlantic slave trade was quite modest, accounting only for 6 percent of overall commerce in the period between 1514 and 1866. A comparative analysis of the number of voyages organised by state-sponsored companies sailing under different flags also points to identical results, representing less than 10 percent of the total share for each flag.

The sole exception is the Netherlands for which the number of voyages organized by the WIC and the Middleburg Commercial Company (MCC) accounted for around 35 percent of the slave voyages carried out under the Dutch flag. ${ }^{3}$ It is likely, however, that the participation of state-sponsored companies in the Dutch slave trade is over-represented, as recent scholarship in this field has shown that it was common practise for these companies, especially the first and second WIC, to rely on the services of private merchants and entrepreneurs to conduct many of their inter-continental commercial and shipping activities. In this study we aim, therefore, to give private participation in the slave trade the attention it deserves, given its weight in the overall volume of trade as a way to better our knowledge and understanding of early modern merchants and their relationship with colonial economies and empires.

Although the TSTD has provided us with an impressive collection of data on slave voyages, including details on ship owners and captains, little is known about private merchants' participation in the transatlantic slave trade. The studies of Vila Vilar, Franco Vega, Miller, Newson and Michin, and Green, among others, focusing mainly on Portuguese private engagement in this commerce are some of the few exceptions. ${ }^{4}$

Most of these studies have, however, concentrated their attention on the activities of groups of private merchants who operated solely or mainly with

3 Calculations made by the author on the basis of the information available on http://www .slavevoyages.org, 20-06-2012.

4 Enriqueta Vila Vilar, "La sublevacíon de Portugal y la trata de negros". Ibero-Americanks Archiv 2 (1976): 171-192. Enriqueta Vila Vilar, Hispanoamerica y el comercio de esclavos. Sevilla: Escuela de Estudios Hispano-Americanos, 1977. Marisa Vega Franco, El trafico de esclavos con Americas. Asientos de Grillo y Lomelini, 1663-1674. Sevilla: Escuela de Estudios HispanoAmericanos, 1984: 194-202. Joseph C. Miller, "Capitalism and Slaving: The financial and Commercial Organization of the Angolan Slave Trade, according to the Accounts of Antonio Coelho Guerreiro (1684-1692)". The International Journal of African Historical Studies 17, no. 1 (1984): 1-56. Linda A. Newson and Susie Minchin, From Capture to Sale: The Portuguese Slave Trade to Spanish America in the Early Seventeenth Century. Leiden: Brill, 2007. Toby Green, The Rise of the Trans-Atlantic Slave Trade in Western Africa, 1300-1589. Cambridge: Cambridge University Press, 2012. 
members of their own group, whether this group was ethnic-, religious-, or kinbased. This scenario contrasts with other Atlantic areas and commercial branches for which private merchants' activities and cross-cultural businesses networks have been examined and well-documented in various recent studies. ${ }^{5}$ Schnurmann, Studnicki-Gizbert, Ebert, Trivellato, and Antunes are some of the most important contributions. ${ }^{6}$ These authors have not only clearly shown the role played by private businessmen in the making of the early modern Atlantic economy, but have also devoted more attention to the study of the involvement of merchants in financial and commercial ventures with partners outside of their traditional business connections, including family, friends and the firms - also known as the F-connection. ${ }^{7}$ In other words, individuals that engaged in transactions with members of other cultural groups are regarded as cross-cultural. Here, it is also our goal to study the business relationships established between merchants of different ethnic, religious

5 Peter A. Coclanis (ed.), The Atlantic Economy During the Seventeenth and Eighteenth Century: Organization, Operation, Practice, and Personnel. Columbia: University of South Carolina Press, 2005. John J. McCusker and Kenneth Morgan (eds.), The Early Modern Atlantic Economy: Essays on Transatlantic Enterprise. Cambridge: Cambridge University Press, 200o. Diogo Ramada Curto and Anthony Molho (eds.), Commercial Networks in the Early Modern World. Florence: European University Institute, 2002.

6 Claudia Schnurmann, "Atlantic Trade and Regional Identities: The Creation of Supranational Atlantic Systems in the 17th Century". In Atlantic History: History of the Atlantic System: 15801830. Edited by Horst Pietschmann. Göttingen: Vandenhoeck \& Ruprecht, 2002: 179-198. Claudia Schnurmann, "Representative Atlantic Entrepreneur: Jacob Leisler, 1640-1691". In Riches from the Atlantic Trade: 259-286. Daviken Studnicki-Gizbert, "Interdependence and the Collective Pursuit of Profits: Portuguese Commercial Networks in the Early Modern Atlantic". In Commercial Networks: 90-120. Daviken Studnicki-Gizbert, "La 'nation' portugaise. Réseaux marchands dans l'espace atlantique à la époque moderne". Annales Hss 58 , no. 3 (2003): 627-648. Daviken Studnicki-Gizbert, A Nation upon the Ocean Sea. Portugal's Atlantic Diaspora and the Crises of the Spanish Empire, 1492-1640. Oxford: Oxford University Press, 2007. Christopher Ebert, "Dutch Trade with Brazil before the Dutch West India Company, 1587-1621" in Riches from Atlantic Trade: 49-76. Christopher Ebert, Between Empires: Brazilian Sugar in the Early Atlantic Economy, 1550-1630. Leiden: Brill, 2008. Francesca Trivellato, The Familiarity of Strangers. The Sephardic Diaspora, Livorno, and Cross-Cultural Trade in the Early Modern Period. New Haven: Yale University Press, 2009. Cátia Antunes, "Investimento no Atlantico: redes multiculturais de negocio, 1580-1776". In XV Congresso Internacional de AHILA, 1808-2008: Crisis y problemas en el mundo Atlántico. Leiden: AHILA, Depto. de Estudios Latinoamericanos, 2010. Jessica Vance Roitman, The Same but Different? Inter-Cultural Trade and the Sephardim, 1595-1640. Leiden: Brill, 2011.

7 Y. Ben-Porath, "The F-connection: Families, Friends and Firms and the Organization of Exchange". Population and Development Review 6 (1980): 1-30. 
and cultural affiliations ${ }^{8}$ for the operation of the slave trade, leading to the formation of cross-cultural business networks extending across the borders of various European empires. ${ }^{9}$

During the early modern period, Portuguese, Sephardic Jews, Dutch, Flemish and German businessmen based in the Dutch Republic, Portugal and other places in Europe, as well as in Spanish America, Brazil, Angola and Mozambique were at the heart of this complex system of interactions. ${ }^{10}$ They will be the prime focus of this study. Here, we will look into their activities during the seventeenth and eighteenth centuries.

By analysing two chronological periods and connections between multiple geographical areas we aim to explore how the establishment of these networks might have aided private initiative to defy and or cooperate with monopolies imposed by states or state-sponsored companies.

Our analysis is based on a selection of case studies made accordingly to the quality and number of relevant primary sources gathered in Portuguese and Dutch archives. ${ }^{11}$ The study of these primary materials is complemented with

8 Philip D. Curtin, Cross-Cultural Trade in World History. Cambridge: Cambridge University Press, 1984.

9 M. Casson, "Economic Analysis of Social Networks". In Actas del X Simposio de Historica Economica. Análisis de Redes en la Historia Economica. Bellaterra: CD-Rom, 2005.

10 On the Portuguese Sephardim in the Republic, Western Europe and the Atlantic in general, see: Jonathan I. Israel, European Jewry in the Age of mercantilism, 1550-1750. London: Clarendon, 1998. Jonathan I. Israel, Diasporas within the Diaspora: Jews, Crypto-Jews, and the world maritime empires (1540-1740). Leiden: Brill, 2002. Y. Kaplan, An alternative to modernity. The Sephardi Diaspora in Western Europe. Leiden: Brill, 200o. Daniel M. Swetschinski, Reluctant Cosmopolitans. The Portuguese Jews of seventeenth-century Amsterdam. London: The Littman Library of Jewish Civilisation, 2000. On the mercantile group in Portugal and the Portuguese Empire, see: Leonor Freire Costa, Impérios e grupos mercantis. Entre o Oriente e o Atlântico (século XVII). Lisbon: Livros Horizonte, 2002. Leonor Freire Costa, O transporte no Atlântico e a Companhia Geral do Comércio do Brasil (1580-1663). 2 vols. Lisbon: Comissão Nacional para as Comemorações dos Descobrimentos Portugueses, 2002. José Gonçalves Salvador, Os magnatas do tráfico negreiro (séculos XVI e XVII). São Paulo: Pioneira Editora, 1981. David Grant Smith, The Portuguese Mercantile Class of Portugal and Brazil in the 17th century: a Socioeconomic Study of Merchants of Lisbon and Bahia, 1620-169o (unpublished dissertation, University of Texas at Austin, 1975). Roitman, The Same but Different?.

11 Some of the materials presented here are also partially integrated into my Ph.D. dissertation, titled "The Dutch and the Portuguese in West Africa: Empire Building and Atlantic System: 1580-1674," defended at Leiden University in June 2009 (published with the title Dutch and Portuguese in Western Africa: States, Merchants and the Atlantic System, $1580-$ 1674. Leiden: Brill, 2011). 
information available in the TSTD and secondary literature. Let us start, however, by briefly examining the juridical framework that regulated the participation of private merchants in the transatlantic slave trade.

\section{Legal Frameworks for Private Participation in the Transatlantic Slave Trade: The Iberian and Dutch Cases}

During the early modern period the juridical framework regulating private participation in the transatlantic slave trade within the sphere of influence of the Iberian Crowns and the Dutch Republic underwent several changes. Those changes affected the business prospects for private merchants and the level of risk involved in financial and commercial transactions associated with the slave trade, both directly and indirectly, leading to possible changes in terms of networks' formation and operation.

Portuguese trade with western Africa had been a monopoly since the midfifteenth century. To organize trade and prevent the intervention of smugglers, the Crown had established monopolies and several factories in the GuineaBissau region, Cape Verde, and São Tomé. However, by the late fifteenth century, the Crown started to grant private merchants trading licenses to operate within certain areas and with a specific range of goods as well as to lease direct management of the different monopolies to private interests. Between the 1530 and 1640 , the latter became common practice. The monopolies of the Cape Verdean and Guinean, São Tomé, and Angolan trades were leased regularly to private businessmen, named as contratadores. ${ }^{12}$

12 Jill Dias, "As primeiras penetrações portuguesas em África" in Portugal no Mundo. Edited by Luís de Albuquerque. Vol. 1. Lisbon: Publicações Alfa, 1989: 285. Marília Lopes, "A exploração económica da Guiné e de Cabo Verde”. In Portugal no Mundo. Vol. 1: 252. Maria Teresa da Silva Diaz de Seabra, Análise organizacional de S. Jorge da Mina: perspectivas da colonização Portuguesa na Costa Ocidental Africana (unpublished MA thesis, University of Lisbon, 200o): 80-92. J. Bato' Ora Ballong-Wen-Mewuda, São Jorge da Mina, 1482-1637: la vie d'un comptoir portugais en Afrique occidentale. Vol. 1. Lisbon/Paris: Fondation Calouste Gulbenkian, 1993: Chapters 2 and 3. Maria Manuel Torrão, "Rotas comerciais, agentes económicos, meios de pagamento". In História geral de Cabo Verde. Edited by Maria Emília Madeira Santos. Vol 2. Lisbon/Praia: Centro de Estudos de História e Cartografia Antiga, Instituto Nacional da Cultura de Cabo Verde, 1995: 17-123. Zelinda Cohen, "Subsídios para a história geral de Cabo Verde: os contratos de arrendamento para a cobrança das rendas e direitos reais das ilhas de Cabo Verde (150o/156o)". Studia 53 (1994): 336-338. Fréderic Mauro, Portugal, o Brasil e o Atlântico (1570-1670). Vol 1. Lisbon: Editorial Estampa, 1997: 217-218. 
The contratadores had permission to trade and to place their own factors and assistants in the different regions. They were also allowed to grant avenças (trading licenses) to other private merchants. The avenças were contracts authorizing the avençador (license holder) to export a certain quantity of a given product within a specific geographical area. According to these contracts, the contratadores would cover the risks involved in the transport, such as shipwreck, fire, and capture by pirates and corsairs. The other party had permission to load the quantity of goods mentioned in the contract in a specific port. The contratador or his agents could sell these trading licenses, in either Portugal or the Atlantic possessions. To avoid losses, they could demand a fiança (pledge of goods) from the avençadores.

In addition, during the fifteenth century, in an attempt to promote settlement and economic development, the Crown also made several royal donations of overseas lands to noblemen (the so-called donatários and capitães-donatários), which included administrative and judicial powers, as well as commercial freedoms. As a consequence, the donatários, capitães-donatários and the settlers of Cape Verde, São Tomé and Angola held royal permission to trade with the nearest regions of the African continent, opening the door for another stream of private participation in the slave trade, as well as in other businesses..$^{13}$

On the other hand, throughout the Union of the Iberian Crowns (15801640), the Portuguese commercial and financial community were also able to hold contracts from the Spanish royal monopolies. ${ }^{14}$ The Spanish asiento Spain's monopoly over the trading licenses for the regular supply of African slaves to the Spanish American colonies - was among those contracts. Between 1586 and 1640, Portuguese businessmen monopolized the system of asientos. By simultaneously holding the Spanish asiento and the Portuguese royal

13 Francisco Bethencourt, "Political Configurations and Local Powers". In Portuguese Oceanic Expansion. Edited by Francisco Bethencourt and Diogo Ramada Curto. Cambridge: Cambridge University Press, 2007: 197-254. António Vasconcelos de Saldanha, As capitanias e o regime senhorial na expansão ultramarina portuguesa. Funchal: Secretaria Regional do Turismo, Centro de Estudos de História do Atlântico, 1992. Cristina Maria Seuanes Serafim, As ilhas de São Tomé no século XVII. Lisbon: Centro de Estudos de AlémMar da Universidade Nova de Lisboa, 2000: 11-13. Isabel Castro Henriques, "O ciclo do açúcar em São Tomé nos séculos XV e XVI”. In Portugal no Mundo. Vol 1: 269. Luís de Albuquerque, "A colonização de São Tomé". In Portugal no Mundo. Vol. 2:174; Maria Manuel Torrão, “Colonização de Cabo Verde: meios e objectivos". In Portugal no Mundo. Vol. 2: $165^{-166 .}$

14 Leslie Brennan Rout, Jr., The African Experience in Spanish America. Cambridge: Cambridge University Press, 1976: 37-61. Vila Vilar, Hispanoamerica: 23-59. 
monopolies on the African trade, these merchants managed to control both the major supply and the consumer markets for slave labour.

After the Portuguese Restoration in 1640, the Portuguese merchants who held the asiento at the time abandoned Seville, and the links of the Portuguese mercantile elite based in Lisbon to the transatlantic slave trade appeared to weaken. ${ }^{15}$ Between the 1640 s and 1670 s, most contratadores of the Angolan royal monopoly were citizens and merchants based in Luanda. ${ }^{16}$ Whereas in the last quarter of the seventeenth century, the role played, in part, by the contratadores was taken over by several commercial companies chartered by the crown and given monopoly rights over the trade with Brazil and various regions of western Africa. ${ }^{17}$ The establishment of these companies did not, however, remove private merchants from the slave and other colonial trades.

Thus, from the early sixteenth century, private merchants controlled the Crown monopolies in western Africa, including the slave trade. These regulations opened a window for the legal participation in the colonial trade for them, but simultaneously created enough room for private initiatives that also challenged the monopolies, either through tax evasion, smuggling, and other types of transactions deemed as 'illegal' by the states and companies.

In the Dutch Republic, trade with western Africa, including the slave trade, was controlled by private businessmen until 1621. In the main Dutch port cities, there were a handful of private firms and several independent businessmen involved in these commercial branches. ${ }^{18}$ These private firms had no formal commercial organization comparable to the wIC, and only hired merchants and accountants aboard ships, onshore, or aboard floating trading posts. ${ }^{19}$

15 Enriqueta Vila Vilar, Aspectos sociales en América colonial. De extranjeros, contrabando y esclavos. Bogotá: Instituto Caro y Cuervo, Universidad de Bogotá Jorge Tadeo Lozano, 2001: 119-130.

16 Salvador, Os magnatas: 52-54. Eunice R.J.P.L. Jorge da Silva, A administração de Angola: século XVII (unpublished MA thesis, University of Lisbon, 1996). Vol. 1: 221-253.

17 Daniel Pereira, "A fundação da Companhia de Cacheu, 1671-1676". In Mansas, escravos, grumetes e gentio: Cacheu na encruzilhada de civilizações. Edited by Carlos Lopes. GuineaBissau/Lisbon: Instituto Nacional de Estudos e Pesquisa, Imprensa Nacional da Casa da Moeda, 1993: 207 and 215. Costa, O Transporte. Vol. 1: Chapters 1 and 2. António Carreira, As companhias pombalinas de navegação, comércio e tráfico de escravos entre a Costa Africana e o Nordeste Brasileiro. Porto: Imprensa Portuguesa, 1969.

18 W.S. Unger, "Nieuwe gegevens betreffend het begin der vaart op Guinea, 1561-1601". Economisch-historisch Jaarboek 21 (1940): 194-217. Enthoven, "Early Dutch Expansion": $17-48$.

19 Andreas Josua Ulsheimer, "Andreas Josua Ulsheimer's voyage of 1603-4". In German sources for West African history, 1599-1669. Edited by Adam Jones. Wiesbaden: Steiner, 1983: 21-29. Samuel Brun, "Samuel Brun's voyages of 1611-1620". In German Sources: 45-96. 
The establishment of the wIC by the States-General in 1621 brought to an end this initial period of free trade, by granting the WIC a monopoly over all Atlantic commerce. $^{20}$

From its outset, the chartering of the WIC was met with great opposition from the merchants of Amsterdam and the northern port cities of the Republic, who had important investments in the north Atlantic fisheries, Brazilian sugar and dyewood, the salt trade with South America, and the African gold, ivory, and slave trades. Some commercial branches were, therefore, detached from the WIC monopoly soon after its establishment. The Brazilian and African trades, however, remained under the WIC's control, but not without hampering profits for both the WIC and the private merchants.

Between the mid-1630s and 165 os, the military character of the wIC caused the disruption of many activities in Brazil and western Africa, while, in the Republic, the burden of paying for the huge military campaigns against the Portuguese possessions in the Atlantic began to be felt. ${ }^{21}$ As early as the mid1630 s, the WIC lacked the cash flow to operate its businesses in Brazil, western Africa, the Caribbean, and North America and struggled to ensure the transport of commodities, personnel, and weaponry between its posts and settlements. To mitigate its losses, the WIC gave shareholders permission to participate in the trade with Brazil and the Caribbean in 1638. In 1647, the wIC also agreed to open the slave trade from Angola to Brazil, the Caribbean, and the Spanish Americas to private merchants. Finally, in 1648, the trade with North America, including the slave trade, was opened to private merchants from the Republic. This shift in the wIC policies opened a wide range of opportunities for businesses in the Republic, and it meant that, for substantial periods of the sixteenth and seventeenth centuries, private merchants controlled most of the Atlantic commerce, including the slave trade.

Pieter van den Broeke, Pieter van den Broecke's journal of voyages to Cape Verde, Guinea and Angola (1605-1612). Edited by J.D. La Fleur. London: Hakluyt Society, 2000: 28, 47, 83-103.

20 Emmer, "The West India Company": 71-95. Heijer, De geschiedenis van de wic: Chapters 1-3. Boogaart and Emmer, "The Dutch participation in the Atlantic Slave Trade": 353-375.

21 Ebert, "Dutch Trade with Brazil": 49-76. Ebert, Between empires: Chapters 3, 5-6. Klaas Ratelband, Nederlanders in West-Afrika (160o-1650): Angola, Kongo en São Tomé. Zutphen: Walburg Pers, 2000. [Portuguese Trans. Os Holandeses no Brasil e na Costa Africana. Angola, Kongo e São Tomé (16oo-1650) (Lisboa: Vega, 2003)]. Michiel A.G. de Jong, 'Staat van oorlog': wapenbedrijf en militaire hervorming in de Republiek der Verenigde Nederlanden, 1585-1621. Hilversum: Verloren, 2005. 
The only branch of Atlantic trade that remained as a wic monopoly was the trade in gold. ${ }^{22}$

The bankruptcy of the first WIC in 1674 and the process leading to the chartering of a second company under the same name, did not introduce major changes to the legal framework already in place. Although, the second wic held a nominal monopoly over Dutch participation in the slave trade, including activities in Loango and Angola, and had administrative, fiscal and military authority to enforce this monopoly, ${ }^{23}$ more often than not the transatlantic slave trade remained in the hands of private entrepreneurs and merchants in the Republic and their partners elsewhere. In time, the wIC became primarily an administrative, fiscal and military organization, responsible for the maintenance and administration of outposts in western Africa as well as taxation on trade, while private firms appeared to dominate the trade itself. This was reflected in the increasing activities of interlopers in the Company monopoly. ${ }^{24}$ It continued with the formation of multiple small, medium and large-sized companies in Dutch ports and their increasing role in the commerce between the Republic, western Africa, and particularly the Loango and Angolan regions. The MCC, founded in 1720 , is the best known example of such private independent consortia. ${ }^{25}$

22 Emmer, "The West India Company": 79-81. Cornelius Goslinga, The Dutch in the Caribbean and on the Wild Coast, 1580-1680. Assen: Van Gorcum, 1990: 110. J.G. van Dillen, Van rijkdom en regenten, handbook tot de economische en sociale geschiedenis van Nederland tijdens de Republiek. 's-Gravenhage: Martinus Nijhoff, 1970: 169.

23 Heijer, Geschiedenis van der WIC. Henk den Heijer, Goud, ivoor en slaven: scheepvaart en handel van de Tweede Westindische Compagnie op Afrika, 1674-1740. Zupten: Walburg Pers, 1997.

24 Ruud Paesie, Lorrendrayen op Africa: de illegale goederen- en slavenhandel op West-Afrika tijdens het achttiende-eeuwse handelsmonopolie van de West-Indische Compagnie, 170o1734. Amsterdam: De Bataafsche Leeuw, 2008.

25 Simon J. Hogerzeil and David Richardson, "Slave Purchasing Strategies and Shipboard Mortality: Day-to-Day Evidence from the Dutch African Trade, 1751-1797". The Journal of Economic History 67, no. 1 (2007): 160-19o. Victor Enthoven, "Dutch Crossings". Atlantic Studies 2, no. 2 (2005): 153-176. Corrie van Prooijen, Van goederenhandel naar slavenhandel: de Middelburgse Commercie Compagnie 1720-1755 (unpublished PhD dissertation, Leiden University, 2000). Johan Francke, Armazoen voor cargazoen: slavenhandel door de Middelburgsche commercie compagnie (1732-1804). Middelburg: J. Francke, 1996. R.A. Hezemans, De Atlantische slavenhandel der Middelburgsche Commercie Compagnie. Leiden: Leiden University, 1985. J.P. van de Voort, Handel en handelsbetrekkingen met West-Indië: wording en bedrijf van de Middelburgsche Commercie Compagnie 1720-1780. Nijmegen: [s.n.], 1967. W.S. Unger, Bijdragen tot de geschiedenis van de Nederlandse 
Although states and state-sponsored companies regulated the participation of private merchants in their commercial monopolies, they struggled to enforce this legislation. This fact opened up broad opportunities for individuals to engage in commercial activities that fell out of the aforementioned legal framework, creating business portfolios and networks that simultaneously combined legal and "illegal" transactions, and explored the voids in the regulations to their own advantage. In this process, royal officers and companies' employees on-the-spot also played an important role.

In the following two sections of this study we will examine in detail four case studies in an attempt to emphasize the advantages (and/or disadvantages) of these business networks as mechanisms to challenge, defy and/or cooperate with the monopolies of the Iberian Crowns and the Dutch statesponsored companies, among others.

\section{Slave Trade Monopolies and Private Networks in the Seventeenth Century: The Iberian and the wIC Monopolies and the Sephardi and Christian Networks}

Between ca. 1590 and 1623 , the Republic was home to two groups of merchants with economic interests in the slave trade: a group of Christian merchants of Dutch, Flemish, and German origin (hereafter referred to as Dutch) and the Portuguese Sephardim established in Amsterdam and other Dutch cities.

The Dutch merchants started their economic activities in the south Atlantic in the late 1580 , mainly investing in the Brazilian sugar and dyewood trades and the African commerce in gold, ivory and leather ${ }^{26}$ In these early years, Dutch participation in the slave trade was minimal, as the studies by Postma, Eltis, and Vos, et al. have demonstrated. ${ }^{27}$ There are, however, several examples of ships connecting the Republic to western Africa and traveling back to Europe via Brazil, the Spanish West Indies, Jamaica and Martinique, and the Guianas, transporting slaves. Many of these voyages were organized by members of the Portuguese Sephardic community based in Amsterdam and other

slavenhandel II: de slavenhandel der Middelburgsche commercie compagnie 1732-1808. 's-Gravenhage: Nijhoff, 1961.

26 See, for example, Amsterdam Municipal Archives (hereafter sAA), Notarial Archives (hereafter NA), 376/114-115: 6 March 1613; NA, 376/114-115: 6 March 1613.

27 Postma, The Dutch in the Atlantic Slave Trade: Chapter 1. Postma, "A Reassessment of the Dutch Atlantic Slave Trade": 158-138. Vos, Eltis, and Richardson, "The Dutch in the Atlantic World": 228-249. 
Dutch ports, either single-handedly or in partnership. ${ }^{28}$ The commercial webs setup by the Portuguese Jews of Amsterdam encompassed various European States (i.e. the Republic, Portugal, Spain and, at times, Flanders, France and several Italian cities), as well as Upper and Lower Guinea, Angola, Brazil, and the Spanish West Indies and thus covering both Iberian Empires. Diogo Nunes Belmonte is a case in point.

In order to organize his involvement in the transatlantic slave trade, Belmonte had connections in Europe, Western Africa and the American colonies. In Europe, Belmonte appeared associated with Sebastião Ribeiro and Manuel Carvalho, both Portuguese Sephardic Jews based in Amsterdam. Belmonte and Ribeiro had also connections in Lisbon with Custódio Lobo da Costa, whereas in the West Indies their main contact person seems to have been Francisco Ribeiro. Let us start with Sebastião Ribeiro. He was not only an investor in the slave voyages organized by Belmonte, but he also acted as skipper on several occasions. In 1613, De Engel Michiel, for example, was freighted by Belmonte and Ribeiro. Ribeiro acted as the skipper and was instructed to purchase slaves in Angola and sell them in the West Indies.Jamaica, Martinique, and the coast of Honduras were some of the ports recommended for disembarkation. The vessel was to return to Seville with bullion, gold, silver and other commodities. ${ }^{29}$

Custódio Lobo da Costa, on the other hand, was Ribeiro's brother. Da Costa was also a merchant, but based in Lisbon. On several occasions, he was recruited as skipper and representative of Belmonte and Ribeiro. The Espirito Santo da Nazaré, freighted by them in 1623 , was skippered by Da Costa. The vessel was to sail from Lisbon to Seville. Here, Da Costa was in charge of taking care of all paper work at the Casa de la contratacion and obtained the required permissions to sail to the Spanish West Indies - the vessel's main destination. ${ }^{30}$ From Seville, the ship was to head South to Angola, where Da Costa was responsible for acquiring slaves. ${ }^{31}$ Thus, as skippers, both Ribeiro and his brother were responsible for the transport of exchange commodities from the Republic to Africa, often via Lisbon and Seville. In these two ports, they were in charge of purchasing an avença from the Portuguese contratador of the Angolan trade as well as trade licenses from the holders of the Spanish asiento. They were also expected to solve unexpected problems, such as delays in ports

\footnotetext{
28 SAA, $N A, 254 / 188-188 \mathrm{v}$ : 22 May 1614; $N A$, 164/162: 11 November 1620.

29 SAA, $N A$, 258/81: 19 March 1613; $N A, 254 / 188-188 v$ : 22 May 1614.

$30 \quad$ For further details on these bureaucratic procedures, see: Newson and Minchin, From Capture to Sale: Chapter 1.

31 SAA, $N A, 646$ A/394: 28 March 1623.
} 
or lack of commodities and enslaved Africans in the ports of embarkation and issues related to disembarkation, the sale of commodities and the purchase of return cargos.

In this business, Manuel de Carvalho, also Portuguese and based in Amsterdam, acted as credit provider. For instance, in 1617, Carvalho had granted commercial credit to Belmonte for the venture of the St. Michiel. The ship had been freighted by Belmonte and skippered by Sebastião Ribeiro to transport slaves from Angola to the Spanish West Indies. Here, Francisco Ribeiro was Belmonte's contact person. In 1617, Francisco sent to Seville a return cargo on board to De Capitaine Francisco Ferreira. ${ }^{32}$

In the slave voyages organized by the Belmonte family and its associates, the cargos on board the ships were insured by Anthoine van Dimen, Albert Schuijt, Wijbrant Warwijck, Hans van Soldt de Jonge, Pelgrom van Dronckelaer, and Samuel Voerknecht, among many others. For example, in 1614, they insured for Diogo Nunes Belmonte the slaves transported on board the ship De Engel Michiel, as well as the return cargo of gold, silver, and other commodities. Captain Sebastião Ribeiro was hired to sail the Luanda-West Indies-Seville route. ${ }^{33}$

Hence, the commercial interests of the Portuguese Sephardic Jews of Amsterdam and their agents crossed the geographical boundaries of several Atlantic empires, encompassing not only the Iberian Atlantic, but also areas like Jamaica and Martinique, which were under the increasing influence of the English and French. Their networks had a trans-imperial character not only from a commercial view point, but also in the financial organization of the ventures and their insurance.

As importantly, Belmonte's network and the roles played by his partners and their activities within the business web clearly show how it was possible for private merchants and entrepreneurs to operate successfully within the legal frames imposed by monopolistic states, like the Iberian Crowns. Simultaneously, this example demonstrates how it was possible for foreign investors such as the German, Flemish and Dutch, who were legally not authorized to participate directly in the Iberian slave trade and other colonial trades, to engage in these commercial branches indirectly by covering the risks of the voyages organized by this network, and, in this way, defying the rules of operation of the Iberian monopolies. In addition, the Belmonte case also calls our attention to the advantages that cross-cultural networks offer their members in terms of strategies to draw capital from different sources, and to benefit from combining

32 SAA, NA, 146/199v-20ov: 23 February 1617.

33 Ibidem. 
know-how about European and colonial supply and consumption markets, and about the modus operandi through the bureaucratic apparatus of Iberian monopolies and their surveilling institutions, namely the Casa da Índia in Lisbon and the Casa de la Contratación, in Seville.

Combining both legally-bounded and defiant business activities was not only a reality within the Iberian monopolies on the slave trade and colonial commerce, but was also a common practice within the state-sponsored monopolistic companies, such as the Dutch WIC. From a legal point of view, the establishment of the WIC by the States-General in 1621 required private merchants in the Republic to abandon their participation in the Atlantic commerce. By 1623 , these regulations were enforced and the latter had to bring their activities to a halt. Many protested, and others devised strategies to continue operations in these areas. These included the use of passports from nonDutch cities, ports of departure outside of the Republic, and instructions to supercargoes to trade in areas out of the reach of the jurisdiction of the WIC, due to the threat of confiscation of the vessel and cargo by the wic. ${ }^{34}$ Both the Portuguese Sephardim and the Dutch made use of these strategies. ${ }^{35}$

However, as was mentioned earlier, the strict monopoly of the wIC did not last long due to the financial and commercial difficulties faced by the company. From the mid-163os, individuals were authorized to participate in the monopoly trade and as early as the mid-1640s an increasing number of Dutch merchants chose to cooperate with the WIC and comply with her trade regulations as a strategy to improve their business opportunities. Henrico Mathias, a merchant of German descent based in Amsterdam in the second half of the seventeenth century, is a case in point.

On August 1, 1657, Henrico Mathias signed a contract with the directors of the WIC to deliver slaves to Curaçao on the ship De Coninck Salomon. ${ }^{36}$ Like Mathias, Heerman Abrahamsen, and their associates, as well as Balthasar and Joseph Coymans - all merchants in Amsterdam - also signed agreements with the WIC for the supply of slaves to the Dutch Caribbean and the Spanish Americas, in 1662 and 1675 , respectively. ${ }^{37}$

At the same time, and in an identical way as the Belmonte case analysed earlier, they too associated themselves with business partners outside their natural group in a clear attempt to capitalize on the know-how these outsiders

34 SAA, NA, 2757A/153: 9 April 1661; NA, 2757A/149: 9 April 1661.

35 SAA, $N A$, 420/536: 20 December 1639; NA, 169o/599: 16 April 1648.

36 SAA, $N A, 2118: 1$ August 1657.

37 SAA, NA, 1996A/113: 28 April 1663; NA, 322/675-699: 27 April 1675; NA, 3221/695: 27 April 1675 . 
had of business in European, African and American markets, and their knowledge of the legislation and legal procedure in use in each commercial branch and region under the control of the different monopolistic entities.

Mathias' activities have left us with a paper trail that allows us to reconstruct, at least in part, his cross-cultural and trans-imperial slave trade networks. He started his economic activities in the Atlantic in the 1650 s and remained active until the 1670 s, showing clear interests in western Africa, Brazil, the Caribbean Islands, New Netherland, and the Spanish American colonies in both South and Central America and the West Indies.

In order to organize the slave trade, Mathias had connections in Europe, western Africa and the American colonies. In Europe, Henrico Mathias appeared associated with Jacinto Vasques, a merchant in Seville with investments in the slave trade, as well as with Marcelo van der Goes and Philip van Hulten, merchants in Amsterdam. ${ }^{38}$ Whereas in London, Jacob Luce (possibly Jacob de Luz? of Portuguese Sephardic origin) had power of attorney and commercial credit from Mathias to recover goods seized by English privateers. ${ }^{39}$

In western Africa, Mathias' main activity was the slave trade, though he also participated in other trades. His representatives were present in Angola and on the Gold Coast, more precisely in Mina, Mouri, Cape Coast, Accra and Kormantin. ${ }^{40}$ Here, Henrico kept up regular contacts with the representatives of the wic. ${ }^{41}$

In the trade with the Spanish Central American colonies, including the slave trade, Mathias was associated with Johan van Wickevoort and Jacomo Ruland or Rulant, the first based in Amsterdam and also involved in the Russian trade, ${ }^{42}$ and the latter in Antwerp. ${ }^{43}$ Don Manuel d'Acosta y Souza and Captain Benito d'Almeda, most likely Spaniards, also appeared involved in the slave trade activities of Mathias between Cape Verde area and the Spanish colonies. ${ }^{44}$

In the inter- and intra-continental trade with the Caribbean and, more precisely, Curaçao, Henrico appears associated with Guillelmo Belin le Garde and

38 SAA, NA, 2117/161: 23 November 1656; NA, 2715/207: 10 April 166o.

39 SAA, $N A$, 2120/167-169: 25 May 1657.

40 SAA, $N A$, 2231/100: 10 September 1669 .

41 SAA, $N A, 2717 / 65: 19$ January 1661.

42 Erik Henk Wijnroks, Handel tussen Rusland en de Nederlanden, 1560-1640: een netwerkanalyse van de Antwerpse en Amsterdamse kooplieden, handelend op Rusland. Hilversum: Verloren, 2003: 275. Jarmo Kotilaine, Russia's foreign trade and economic expansion in the seventeenth century: Windows of the World. Leiden: Brill, 2005: 320.

43 SAA, NA, 1131/67-68: 21 October 1659.

44 Nederlandsch Economisch-Historisch Archief (hereafter NE HA), Bijzondere Collecties 471, no. 2.4 Shipping, 2.4.53. Jacomo Rulant, 1660-1662. 
Philip van Hulten. ${ }^{45}$ On the island, Ghijsberto de Rosa (most likely a Spanish captain), ${ }^{46}$ who had conducted trade on their behalf with some inhabitants of the island, the Spanish colonies and the WIC beginning in the early 1660 s, was used as their representative. Edward Man and Isaac van Beeck, directors of the wIC Chamber of Amsterdam, were also important contacts for Mathias' business with Curaçao. ${ }^{47}$

For example, on 1 August 1657, Edward Man and Isaac van Beeck, on behalf of the WIC, received a group of enslaved Africans transported on board the ship Den Coninck Salomon, freighted by Henrico Mathias. An estimated value of 100 silver reales had to be paid for the "cargo." The payment could be made either in currency (usually silver or gold from the Spanish American colonies) or through the selling of goods (such as hides, tobacco, cochenille, compeche-cochenille, silver-cochenille and compeche-hout ${ }^{48}$ ) shipped directly to Amsterdam or via the New Netherland. ${ }^{49}$ Thus, Petrus Stuijvesant, governor of this colony, was also part of Mathias contacts in the Americas. ${ }^{50}$ The relations between Edward Man and Isaac van Beeck (directors of the wIC, Chamber of Amsterdam) and Henrico Mathias went beyond the slave trade. On 4 March 1655, they were authorized by Mathias to obtain permission to release the ship Madama van Brazil, under the command of Captain Hendrick Vroom. The ship and crew were, at the time, retained in Puerto Rico. ${ }^{51}$

In addition, to defend his interests on board the ships, Mathias usually hired a supercargo, both for the ships sailing in the inter-continental circuits linking Europe to the Americas directly and for those going via western Africa. ${ }^{52}$ Mathias also made regular investments in other areas of the Atlantic, including long-distance routes between Brazil, the southern Spanish American colonies and the Republic, as well as coastal trade between Curaçao and New Netherland. ${ }^{53}$

45 SAA, NA, 2211/140-142: 26 July 1661.

46 National Archives of the Netherlands (hereafter NL-HaNa), Resolution Book of Curaçao, no. 58 .

47 SAA, NA, 2118/137: 1 August 1657.

48 Compeche-cochenille and Compeche-hout refer to cochenille and dyewood imported from the hinterland of Spanish America into the port of Campeche in the Yucatan Peninsula and exported from there to Europe and other locations.

49 SAA, NA, 2118/137: 1 August 1657.

50 SAA, $N A$, 2117/161: 23 November 1656 .

51 SAA, $N A$, 2116/45: 4 March 1655 .

$5^{2}$ SAA, $N A$, 1131/67-68: 21 October 1659 .

53 SAA, NA, 2120/167-169: 25 May 1657; NA, 2226/994-997: 28 April 1668. 
Thus, Mathias operated several inter-continental routes connecting Europe, western Africa and the Americas, with the transatlantic slave trade as one of his important areas of investment. In this business, he appeared associated with several directors of the Amsterdam Chamber of the WIC and relied on an extensive network of people including skippers, ship captains, pilots, insurers, credit providers, and supercargoes of different ethnic, religious and cultural backgrounds. Together they acquired essential pieces of information to deal with the monopolistic regulations of the WIC, either to cooperate with the company and/or to circumvent its procedures and to handle the supplydemand patterns of the coastal markets of supply and consumption on both shores of the Atlantic. Some of Mathias' contacts also had good connections with the Spanish authorities in the Caribbean islands, the Spanish American mainland and Spain.

In this process the officials of the WIC on-the-spot, including directors, chief-merchants, and financial officers, among others, played an important role as they could control and supervise commercial transactions and label them as "legal" or "illegal" according the WIC rules. But as importantly, they could engage privately in trade with merchants not authorized to trade within the WIC monopoly areas and commercial branches, or by facilitating tax evasion, bribery, etc. although all these practices would be labelled "corruption" by the WIC directors in the Republic. These were, however, common practices among company officials elsewhere, including the voc servants in Asia, ${ }^{54}$ or the employees of the English and French African companies serving in the Gold Coast in the eighteenth century, as we will see in more detail in the following section.

\section{Slave Trade Monopolies and Private Networks in the Eighteenth Century: Monopoly Holders and the Portuguese-Brazilian Merchant Networks}

In the eighteenth century, alongside various commercial companies and firms, either state-sponsored or built entirely on private initiative (like the MCC), merchants based in Europe and elsewhere in the Atlantic and Indian Oceans kept organizing their commercial activities and networks with eyes fixed not only on the opportunities offered within the empire of their 'home' state or kingdom, but also on locations outside the jurisdiction of their home states.

54 Chris Nierstrasz, In the Shadow of the Company: The voc (Dutch East India Company) and its Servants in the Period of its Decline,1740-1796. Leiden: Brill, 2012. 
Like in earlier periods, their selection of business partners often fell out of their traditional groups - the family, the friends and the firm - to incorporate merchants of other ethnic, religious and cultural backgrounds, based in Europe as well as in different colonial spaces and sometimes even with formal links to other monopolistic entities, either in the capacity of state officials or company employees. These practises become quite evident from an analysis of the Portuguese-Brazilian networks that operated in the Brazil-Gulf of Guinea slave trade circuits during the eighteenth century.

During this period, due to a continuous growth in the demand for slave labour in the Americas, the transatlantic slave trade witnessed a significant increase in terms of the number of voyages, vessels, total number of enslaved Africans transported, and regions of embarkation and disembarkation. In Brazil, the location of mining fields in the interior was one of the major factors contributing to this increase. To cater to these new labour needs of the Brazilian market, while avoiding the strong competition of Portuguese slave merchants already involved in the trade with Angola, and the still stronger presence of Dutch, and foremost the English and French in the Gold Coast, new slave circuits linking Brazil to the Bight of Benin and the Slave Coast (the so-called Costa da Mina ${ }^{55}$ ) emerged after the 1670 . The commercial operations in these routes, which remained active for most of the eighteenth century, offer us an excellent insight into the main topic under scrutiny here.

For most of the first half of the eighteenth century Portuguese-Brazilian ${ }^{56}$ merchants based in the regions of Pernambuco, Bahia, and Rio de Janeiro ${ }^{57}$ resorted to cross-cultural and trans-imperial commercial circuits and financial

55 In the broader sense, the 'Costa da Mina' corresponded to the stretch of the West African coast between Cape Mount and Cape Lopez. For the Portuguese-Brazilian merchants operating in the region, it referred to the ports located between the Volta and the Lagos Rivers. Gustavo Acioli Lopes, Negócio da Costa da Mina e Comércio Atlântico: Tabaco, Açúcar, Ouro e Tráfico de Escravos: Pernambuco (1654-176o) (unpublished PhD dissertation, University of São Paulo, 2008): 176. Pierre Verger, Fluxo e Refluxo do Tráfico de Escravos entre os Golfo de Benin e a Bahia de Todos os Santos: dos séculos XVII a XIX (Salvador: Corrupio, 1997): 37. Philip D. Curtin, The Atlantic Slave Trade: A Census. Madison: University of Wisconsin Press, 1969: 129-130. Patrick Manning, "The Slave Trade in the Bight of Benin, 1640-189o". In The Uncommon Market: Essays in the Economic History of Atlantic Slave Trade. Edited by Henry A. Gemery and Jan S. Hogendorn. New York: Academic Press, 1979: 107, 114-115.

56 In this context, the expression 'Portuguese-Brazilian' referrers to merchants born in Portugal, but resident and/or with main economic activities in Brazil.

57 For further details, see: Manolo Florentino, Em costas negras. Uma história do tráfico entre a África e o Rio de Janeiro. São Paulo: Companhia das Letras, 1997. 
connections to build their business, and often as a strategy to circumvent regulations of the Portuguese Crown concerning the monopoly on the slave trade, in particular the special privileges granted to Bahian slave merchants, who could trade directly with Angola. ${ }^{58}$ During the second half of the eighteenth and the early nineteenth century, the Portuguese-Brazilian networks built between Brazil and the Gulf of Guinea for the slave trade appear to have been, in contrast, a clear strategy to circumvent the monopoly constraints imposed by the Portuguese state-sponsored companies, i.e. the Companhia Geral de Comércio do Grão-Pará e Maranhão and the Companhia Geral de Comércio de Pernambuco e Paraíba established in 1755 and 1756, respectively. 59

Although the Bight of Benin and the so-called "Slave Coast" were never formally under the control of Portugal, throughout the entire early modern period the Portuguese Crown always felt empowered enough to issue various laws regulating the commerce of its subjects and foreigners in these regions. As mentioned earlier, for most of the fifteenth and sixteenth century settlers of São Tomé had been permitted to trade with the so-called Costa da Mina as means to acquire the necessary labour force for the deforestation of the island and the construction of sugar mills and the subsequent production of sugar. In the course of the sixteenth century, Portuguese and foreign merchants in possession of trading licences and/or those holding leases for the Crown's monopoly on the trade with the island of São Tomé, were also granted permission to trade on the region.

The takeover of the Portuguese forts on the Gold Coast, and the temporary occupation of the islands of the Gulf of Guinea by the Dutch wic, all within the context of the Eighty Years War, would lead the Habsburg monarchs to forbid Portuguese subjects from trading in the region. However, the economic decline of the Gulf Guinea Archipelago in the 1650 s and 166os and the difficulties faced by the Portuguese Atlantic economy as a whole led the Portuguese monarchs to lift these trading bans with the Costa da Mina. On 11 March 1673, the Portuguese Crown granted all its subjects ("from this kingdom and the Conquests") permission to trade with the aforementioned Coast. There were, however, a few requirements. Vessels, regardless of their port of registration, had to depart from Portugal. They also had to call at São Tomé on the way to the Coast to pay the duties owed to the Portuguese Crown, with payment being calculated on the basis of the estimated value of the cargo to be acquired on the Coast. ${ }^{60}$

$5^{8} \quad$ Verger, Fluxo e refluxo do tráfico de escravos: 21.

59 Carreira, As companhias pombalinas de navegação.

6o Lopes, Negócio da Costa da Mina: 33-38. Biblioteca Nacional do Rio de Janeiro, Seção de Manuscritos, 11, 3, 1; "Provisão do Conselho Ultramarino. Lisboa, 16 de Março de 1673". 
Finally, transactions were limited to commerce with African traders and not with other European merchants or officials of chartered companies.

Over time, several ports in Brazil were also authorised to trade directly with the Costa da Mina, namely Salvador (Bahia), Rio de Janeiro, and Recife, Goiana and Paraíba (Pernambuco). ${ }^{61}$ This permission also had its caveats. Besides, the last two requirements mentioned above, Portuguese-Brazilian merchants operating in these direct circuits were forbidden to use high quality Brazilian gold and tobacco in these transactions (only low grade tobacco was allowed). European goods used as exchange commodities in the transactions had to be brought from Brazil. Finally, merchants operating in this business were obliged to pay royal duties on the value of the cargoes transported at the ports of embarkation and disembarkation.

It was within this context that Portuguese-Brazilian merchants developed their slaving operations on the Costa da Mina. Manoel Gonçalves Viana and his associate Manoel Correa Seixas, together with Luís Coelho Ferreira and partners are two cases in point. ${ }^{62}$ According to the data available in the TSTD, they

In Cathalogo das Reaes Orderns existentes no arquivo da extinta provedoria de Pernambuco. Edited by Francisco Bezerra Cavalcanti de Albuquerque: 172-173.

61 Lopes, Negócio da Costa da Mina: 142, 149. Florentino, Em Costas Negras. Portuguese Overseas Historical Archive (hereafter AHU), Conselho Ultramarino, Pernambuco, cx. 42, doc. 3738: Lisbon, 31 January 1731: 'Requerimento dos oficiais da câmara de Goiana ao rei, pedindo nova provisão para poderem comercializar livremente escravos de Angola e da Costa da Mina, sem passarem pela capitania de Pernambuco, por mais 6 anos'.

62 The community included merchants based in the major Brazilian ports of the time, Rio de Janeiro, Salvador (Bahia), and Recife (Pernambuco). As briefly mentioned earlier, many of the merchants were of Portuguese origin, but for various reasons based their businesses in Brazil. For further details on these merchants see, for example: Alexandre Vieira Ribeiro, "O comércio das almas e a obtenção de prestígio social: traficantes de escravos na Bahia ao longo do século XVIII". Locus revista de história 12, no. 2 (2006): 9-27. Rae Flory, Bahian Society in the mid-colonial period: the sugar planters, tobacco growes, merchants, and artisans of Salvador and the Recôncavo, 1680-1725 (unpublished PhD diss., University of Texas-Austin, 1978). Jorge Pedreira, Os homens de negócio na praça de Lisboa de Pombal ao Vintismo (1755-1822): Diferenciação, reprodução e identificação de um grupo social (unpublished PhD dissertation, Universidade Nova de Lisboa, 1995). William Donovan, Commercial enterprise and Luso-Brazilian society during the gold rush: the mercantile house of Francisco Pinheiro and the Lisbon to Brazil trade, 1695-1750 (unpublished $\mathrm{PhD}$ dissertation, The John Hopkins University, 1990). Catherine Lugar, The merchant community of Salvador, Bahia, 1780-1830 (unpublished PhD dissertation, State University of New York at Stony Brook, 1980). David Grant Smith, The mercantile class of Portugal and Brazil. Rae Flory and David Grant Smith, "Bahian merchants and planters in the seventeenth and early eighteenth centuries". Hispanic American Historical Review 58, no. 4 (1978): 571-594. John Norman Kennedy, "Bahian Elites, 1750-1822". Hispanic American 
appear to have been the most active slave vessel owners in the region of Bahia in the first and second half of the century. Let us start by looking into Viana and Seixas' activities. Viana started his slave trade business in 1707 and stayed active until 1731. During this period, his single- or co-owned vessels sailed the middle passage forty nine times, thereby connecting the region of Bahia and the so-called Costa da Mina. ${ }^{63}$

Like many other early modern merchants, Viana started his participation in this trade in partnership with other peers: among them were initially António Lopes Ferrão and Manoel Correa Seixas, and, at a later stage, Manoel Francisco Braga, Domingos Azevedo Coutinho, Dionísio Barbosa, and Cipriano da Silva Fernandes. With the exception of Seixas, who appears associated with Viana multiple times, most of these partnerships were established for a single journey, as were, for instance, the associations with Braga, Coutinho and Barbosa for the slave voyage of the shipJesus Maria José in 1722.

Many of these partnerships were established as means to gather enough financial and material resources to organize the slave ventures, but in many cases they were also a way to capitalise on the business experience and knowledge of peers involved in this commerce for a longer period of time. This was, for example, the case of Manoel Correa Seixas, Viana's main associate between 1714 and 1726. In 1707, when Viana came into the business, Seixas had already single-handedly organized at least four slave voyages between Bahia and the Costa da Mina since 1700, the year he entered the business. Until 1714, the year Seixas stopped organizing slave voyages single-handedly, he alone had carried out more than six voyages and several others in partnership.

Although, Viana's associates and the ship captains serving in his vessels were all Portuguese-Brazilian merchants, and the ports of departure and disembarkation visited by his ships were part of the Portuguese Empire, most of the slave purchases in West Africa were carried out in ports outside the sphere

Historical Review 53, no. 3 (1973): 415-439. Marieta Alves, "O comércio marítimo e alguns armadores do século XVIII, na Bahia”. Revista de História de São Paulo 70 (1967).

63 According to the TSDT, Manoel Gonçalves Viana was the individual or co-owner of at least fifteen ships, among which were: the Santo António, Santíssimo Sacramento e Nossa Senhora das Neves, Santíssimo Sacramento Nossa Senhora da Luz, Senhor Bom Jesus de Bouças e Nossa Senhora do Ó e São José, Santíssimo Sacramento Nossa Senhora da Luz e Santo António, Nossa Senhora do Ó e Santo António, Nossa Senhora das Brotas e São Gonçalo, Nossa Senhora da Purificação e Santo António da Barra, Nossa Senhora da Conceição e Santo António da Mouraria, Nossa Senhora do Tejo e Barroquinha, Nossa Senhora das Brotas e Piedade. For further details, see http://www.slavevoyages.org, 07-03-2012. 
of influence of the Portuguese Crown or on the margins of its effective control. ${ }^{64}$ Eighty-nine percent of Viana and Co.'s vessels acquired slaves on the Costa da Mina without specifying the port; eight percent of the voyages obtained their 'cargoes' in the port of Whydah (present-day Benin); two percent in Jacquin (present-day Benin); and two percent in Elmina (present-day Ghana). ${ }^{65}$ As for Seixas' voyages organized individually or in association with others, eighty-two percent of the voyages also acquired slaves in the Costa da Mina, and eighteen percent in Calabar (present-day Nigeria).

Official reports and petitions sent to Lisbon by servants of the Crown in Brazil and São Tomé confirmed the commercial transactions between PortugueseBrazilian merchants and other European traders settled in the region. The Dutch and English were an important connection on the Coast, not only for the purchase of slaves, but, more importantly, to acquire commodities in demand on the Coast and not easily accessible in the Brazilian ports, such as European, Asian and African textiles, alcoholic beverages, beads, etc. To obtain these products, Portuguese-Brazilian merchants like Viana and Seixas used gold extracted from the recently-opened Brazilian mines and tobacco (often high-grade) produced in Alagoas, Pernambuco and Bahia, as exchange commodities. ${ }^{66}$

European merchants and chartered companies based in the region were eager to access these commodities. In the case of the WIC, Postma estimates that between 1715 and 1731, the Company sold an annual average to 200 slaves to Portuguese-Brazilian slavers. ${ }^{67}$ Payments were often made in gold, as the shipments of this mineral by the Company during this period clearly show. ${ }^{68}$ On the other hand, Brazilian tobacco, also called Portuguese tobacco, was reported by officials of the Royal African Company of England (RAC) to be one of the main products traded by the Dutch in certain ports. ${ }^{69}$ These were not,

64 Among the ship captains serving Viana more often were: António Matins, António Martins Carvallho, Manoel Ferreira Lopes, José Marques Brandão, Domingos Barbosa Pereira, António Álvares, Manoel do Couto Santos, Manoel da Costa Porto, Manoel de Andrade, Carlos de Sepulveda de Carvalho. For further details see: http://www.slavevoyages .org: 07-03-2012.

65 For further details on the evolution of Whydah, see: Robin Law, Ouidah: The Social History of a West African Slaving Port. Athens: Ohio University Press, 2004.

66 AHU, São Tomé, cx. 4, doc. 81: Lisbon, 10 July 1721: 'Consulta do Conselho Ultramarino sobre as cartas dos governadores do Brasil e a petição de José de Torres'. See also, Lopes, Negócio da Costa da Mina: 1.

67 Postma, The Dutch Slave Trade: 77-78.

68 Heijer, Goud, Ivoor en Slave.

69 Robin Law, The English in West Africa, 1861-1863: the local correspondence of the Royal African Company of England. Vol 2. Oxford: Oxford University Press, 1997: 171. Roquinaldo 
however, transactions involving only Portuguese-Brazilian merchants and WIC officials. José dos Santos Torres, a merchant of Bahia, operating in the same region in the 1710s-1720s, not only engaged in the sugar trade with Dutch officials on the Coast, but also managed to bring English capital into these deals. ${ }^{70}$ English officials of the RAC were also engaged in transactions with PortugueseBrazilian merchants on the Gold Coast and the Bight of Benin. ${ }^{71}$

Two decades later, these trading practises were still in use. In $175^{2}$, the galley Aleluia da Ressureição e Almas, property of José de Freitas Sacotto, businessman in Recife (Pernambuco), sailed to the Costa da Mina under the command of ship captain José Francisco da Rocha. At the expense of Sacotto and other small investors in the cargo, he acquired brandy, ${ }^{72}$ metal ware, beads, smoking pipes, and different types of textiles ${ }^{73}$ of European, Asian and local origin, on the Coast from the employees of the WIC at Elmina and Anomabu, using mainly tobacco as exchange. The captain also carried trade with an English slaver at Cape Lahou (present-day Ivory Coast) from whom he obtained iron in exchange for tobacco. As for the slave purchases, the captain called at Anomabu, Accra, and Popo - ports outside Portuguese jurisdiction - where he acquired twenty-eight percent of the slave 'cargo', while the remaining seventy-two percent were obtained at Whydah (Ajudá). ${ }^{74}$

Although the Portuguese Crown had built a fort in this port in 1721 with the permission of the King of Dahomé, and a Portuguese-Brazilian community gradually settled in the port, it is very likely that the slave purchases of the Aleluia da Ressurreição e Almas, as well as those of other Portuguese-Brazilian slavers, were not made exclusively with Portuguese-Brazilian traders or their

Ferreira, "A primeira partilha de África: decadência e ressurgência do comércio Português da Costa do Ouro (ca. 1637 - ca. 170o)". Varia Historia 26, no. 44 (Jul.-Dec 2010): 481.

$7 \mathrm{O}$ AHU, Consultas do Conselho Ultramarino, cód. 907, fls. 171-173: 25 October 1721. Roquinaldo Ferreira, "Biografia, Mobilidade e Cultura Atlântica: A Micro-Escala do Tráfico de Escravos em Benguela, século XVIII-XIX". Revista Tempo 20 (2006): 38. G.V. Scammell, "A Very Profitable and Advantageous Trade: British Smuggling in the Iberian Americas circa 1500-1750". Itinerario 24, nos. 3/4 (2000):135-172. Carl Hanson, "Monopoly and Contraband in the Portuguese Tobacco Trade, 1624-1702". Luso-Brazilian Review 19, no. 2 (1982): 161.

71 Ferreira, "A primeira partilha de "Africa": 132.

72 This was very likely Genebra possibly the Dutch Jenever brandwijn or a French cognac.

73 These appear enrolled in various categories including: 'paniscos', 'lenços grossos', algodão vermelho, 'riscado', 'panos brancos, 'chita'.

74 Lopes, "Negócio da Costa da Mina”: 153-170. AHU, São Tomé, cx. 8, doc. 100: Costa da Mina, 1752: 'Entrada da Carregaçam que no Recife de Pernambcuo me consignou o Sr. Jozé de Freitas Sacotto, na sua galera por invocação Aleluya da Surreição e Almas; a mim Jozé Francisco Rocha'. 
agents established there. ${ }^{75}$ The same assumption is also valid for trade conducted by Portuguese-Brazilians at the port of Jacquin, as was the case of Viana and Seixas mentioned earlier. Although the Portuguese Crown had an establishment in this port, ${ }^{76}$ the Dutch built first a trading house, and latter a fort (Fort Zelandia, 1726-1734) ) $^{77}$ there, where they traded regularly with PortugueseBrazilian merchants. An official report from the Portuguese Overseas Council dating from 2 November 1721 stated that in Jacquin the WIC officials sold: 'slaves and merchandise to ships of Bahia in the value of more than one million cruzados every year [paid] in gold powder. ${ }^{78}$ In fact, already in 1707 , the Director of the RAC urged the factors at Cape Coast Castle and Whydah to trade with the Portuguese-Brazilians, especially in gold, merchandise (possibly tobacco, which was a commodity in great demand among the Europeans) and slaves, with the sole condition that the Company factors could not sell European commodities. ${ }^{79}$

Lúis Coelho Ferreira, a prominent merchant in Bahia, is another case in point. Between 1749 and 1784, Ferreira, either alone or in partnership with David de Oliveira Lopes, Manuel Lourenço da Costa, among others, participated regularly in the slave trade with Western Africa. ${ }^{80}$ Although Ferreira's direct partners in this business had the same cultural background and religious affiliations, some of them engaged in the slave trade in areas controlled

75 On the Luso-Brazilian community of Whydah in the late eighteenth and nineteenth centuries, see: Robin Law, "The evolution of the Brazilian community of Ouidah". Slavery and Abolition 22 (2001): 22-41. Robin Law, "A Comunidade Brasileiro de Uidá e os últimos anos do tráfico de escravos, 1850-66". Afro-Ásia 27 (2002): 41-77. Robin Law, "A carreira de Francisco Félix de Sousa na África Ocidental”. Topoi (Mar. 2001): 8-39. See also: Silke Strickrodt, "Afro-Brazilians of the Western Slave Coast in the nineteenth century". In Enslaving connections: changing cultures of Africa and Brazil during the era of slavery. Edited by José C. Curto and Paul Lovejoy. Amherst, N.Y.: Prometheus/Humanity Books, 2003: 213-224. Ana Lúcia Araújo, "Dahomey, Portugal and Bahia: King Adandozan and the Atlantic Slave Trade". Slavery and Abolition 33, no.1 (2012): 1-19.

76 Lopes, "Negócio da Costa da Mina": 62. AHU, Conselho Ultramarino, São Tomé, cx. 4, doc. 106: Lisbon, 23 December 1723: 'Condições dos interessados na Companhia de Curisco'.

77 Albert van Dantzig, Les Hollandais sur la côte de Guinée 1680-1740 à l'époque de l'essor de l'Ashanti et du Dahomey, 1680-1740. Paris: Société française d'histoire d'outre-mer, 1980. Postma, The Dutch in the Atlantic slave trade.

$7_{8}$ Lopes, Negócio da Costa da Mina: 56-57. AHU, Conselho Ultramarino, São Tomé, cx. 4 doc. 85: Lisbon, 2 November 1721: 'Consulta do Conselho Ultramarino sobre a representação de José Torres'.

79 Lopes, Negócio da Costa da Mina: 59. Verger, Fluxo e Refluxo do tráfico de escravos: 57-62. Law, The English in West Africa. Vol. 2: 16; Ferreira, "A primeira partilha de África": 496.

8o http://www.slavevoyages.org: 07-03-2012. Ribeiro, “O comércio das almas": 19-23. 
by the British, including Barbados. Given this fact and the clear English interest and investment in the Brazilian colonial economy during the same period, it is very likely that English capital also found its way into the organization of these Portuguese-Brazilian slave voyages, as was the case in the aforementioned trade of Torres.

In addition, Ferreira and his partners acquired their slave cargoes mainly on the Gold Coast and Bight of Benin - sixty-five percent of the total number of voyages organized. Most likely these human cargoes were purchased from European and African merchants on the Coast, since these areas remained during the second half of the eighteenth century outside of the effective control of the Portuguese Crown. It is also likely that European merchants in these areas, either operating in their own name or on behalf of a specific Statesponsored company, offered better deals. Moreover, the high concentration of trading posts and forts along the Coast under the control of rival European monopolistic companies also increased the possibilities for bargaining on the part of Portuguese-Brazilian merchants as well as their chances for making the best deal.

The remaining thirty-five percent of the slave vessels equipped by Ferreira and partners headed to Benguela, Cabinda and São Tomé. Although these were areas under the formal sovereignty of the Portuguese Crown, they were also removed from the main administrative and fiscal centre of the slave trade at the time which was located in Luanda. The choice of these locations for the acquisition of slaves, in particular Benguela and Cabinda, appears to have been part of a clear strategy on the part of these merchant networks to avoid the constraints imposed by the Portuguese Crown on slave vessels operating in the Angolan trade. All vessels were required to sail via Luanda to allow Portuguese royal officials to inspect and tax cargoes, and, in some cases, to also earn some extra income through bribes. ${ }^{81}$ The dislocation of slave routes and slave trade networks from areas under the effective control of the States and Statesponsored companies continued to be a strategy adopted by private merchants

81 This shift of slave merchants to ports of purchase away from the control of states would be once again visible in the first half of the nineteenth century, as British regulations on the abolition of the slave trade started to be enforced by representatives of British authorities in slave ports and by the patrolling squadrons. Evidence clearly shows the southward dislocation of Portuguese-Brazilian merchants from the Costa da Mina together with African merchants to the port of Benguela. Mariana P. Candido, "Merchants and the Business of Slave Trade at Benguela, 1750-1850". African Economic History 35, no. 1 (2207): 1-30. José C. Curto, "Movers of slaves: The Brazilian Community in Benguela (Angola), c.1722-1832". In, Angola on the Move. Edited by Beatrix Heintze and Achim von Oppen. Frankfurt an Main: Verlag Otto Lembeck, 2008. 
involved in the slave trade well into the eighteenth century. Even commercial firms like the MCC chose areas for the purchase of slaves in Western Africa out of the reach of the jurisdiction and effective control of State and Statesponsored monopolies - in this specific case by concentrating its activities in the Loango and Congo regions.

Thus, from a geographical and commercial point of view, the operations of the Portuguese-Brazilian mercantile communities engaged in the slave trade between Brazil, the Gold Coast, the Costa da Mina or the peripheral regions of Angola, had a trans-imperial character. These businessmen acquired their slave 'cargoes' in areas outside or on the margins of the Portuguese empire and the jurisdiction of the Portuguese Crown, as a way to circumvent the constraints imposed by royal regulations on this commerce. Simultaneously, the enslaved Africans were not only obtained from African merchants and trade representatives of African authorities but also from other European traders settled or operating on the Coast, in most cases Dutch and English. ${ }^{82}$ More importantly, these merchants relied on these Northern European connections to obtain European, Asian and African commodities, especially textiles, alcoholic beverages and weapons (mainly guns), which were either difficult to purchase in Brazil for a good price, or were listed among the merchandise that was forbidden to be traded in Western Africa by Portuguese subjects.

From a logistical point of view, the networks built by many of these merchants, however, do not appear to be trans-imperial like those described for

82 At this level, parallels can also be established with the commercial activities of other European merchants of the time, like for example the French traders of Nantes, Bordeaux, and Le Havre. In most of their slaving operations in the Atlantic, as well as in the Indian Ocean, their ports of slave purchase were often outside the jurisdiction of the French Empire. In the Atlantic, they included the regions of the Gold Coast, the Bight of Benin and the Slave Coast, at the time with a heavy presence and under the relative control of the Dutch and the English. The same pattern can be found in their slave ventures heading to the Indian Ocean. Here, the ports of Mozambique under the relative control of the Portuguese Crown would become their prime locations to obtain slaves for the plantation economies of the French possessions in both regions. Edward A. Alpers, "The French slave trade in East Africa (1721-1810)". Cahiers d'études africaines 10, no. 37 (1970): 80-124. Gwyn Campbell (ed.), The structure of slavery in Indian Ocean Africa and Asia. London: Frank Cass, 2004. Richard B. Allen, Slaves, freedmen, and indentured laborers in colonial Mauritius. Cambridge: Cambridge University Press, 2006. Eduardo Medeiros, O tráfico de escravos de Moçambique para as ilhas do Índico, 1720-1902. Maputo: Núcleo Editorial da Universidade Eduardo Mondlane, 1987. Eduardo Medeiros, O tráfico de escravos nos portos de Moçambique: 1733-1904. Porto: Edições Afrontamento, 2002. António Capela, Dicionário de Negreiros em Moçambique 1750-1897. Porto: Centro de Estudos Africanos da Universidade do Porto, 2007. 
the former century. This was the case for the eighteenth-century PortugueseBrazilian businessmen, mentioned earlier. The vessels employed by the Portuguese-Brazilians in the slave trade between Brazil, the Gold Coast, and Costa da Mina, as well as some of the vessels used in the bilateral commerce between Angola and Brazil, were built in Brazilian shipyards and equipped in the local ports. ${ }^{83}$ In most cases, the ship captain acted as a representative of the interests of both the ship owner and other investors. These ships, like the remaining crew, appear to have been manned by Portuguese- and AfroBrazilian crews recruited locally; some of them were enslaved Africans and were the property of the ship owners themselves. ${ }^{84}$ In this respect, these eighteenth-century Portuguese-Brazilian networks and their modus operandi might be regarded as an exception within the broader context of the transatlantic slave trade, since none of the major slavery-based colonial economies in the English, French, and Dutch Atlantic empires engaged in the direct slave trade with Western Africa or were even authorized by their European colonial masters to build or equip ships for intercontinental trade. ${ }^{85}$

To finance part of the slave ventures some of these merchants did get credit from local sources at least 30 percent interest. Capital required for the voyages could also be obtained by the ship owner by freighting space on the hold of the vessels to individuals, who often invested a small amount of money in commodities to receive, in exchange, one or two slaves from the Costa da Mina. In some cases, however, credit and insurance also appear to have been provided by business partners based in Europe, namely in Portugal and England. This evidence suggests that during the eighteenth century there might have been investment of foreign capital into the Portuguese slave trade as had been the case in the seventeenth century. Further research, however, is needed to assess the levels of investment of financers from other nations in the PortugueseBrazilian slave trade.

83 Lopes, Negócio da Costa da Mina: 149-15o. AHU, Conselho Ultramarino, Pernambuco, cx. 42, doc. 3738: Lisbon, 31 Janeiro de 1731: 'Carta do Governador de Pernambuco'. See also: Anna Amélia Vieira Nascimento, 'Letras de Risco' e carregações no comércio colonial da Bahia, 1660-1730. Salvador: Centro de Estudos Bahianaos/Uf BA, 1977.

84 Ibidem.

85 For further details on the European based organization, finance and insurance of the British, French and Dutch slave trade, see, for instance: David Richardson, "The Eighteenth century British Slave Trade: estimates of its volume and coastal distribution in Africa". Research in Economic History 12 (1989): 151-195. Robert L. Stein, The French Slave Trade in the Eighteenth Century: An Old Regime Business. Madison, Wis.: The University of Wisconsin Press, 1979. Postma, The Dutch in the Atlantic Slave Trade. 


\section{Final Remarks}

The complex connections described above demonstrates clearly that the commercial interests of private merchants involved in the slave trade living in Europe and various colonial areas transcended the political and geographical borders of the various early modern European empires. In addition, it shows that, in many cases, the selection of business partners fell outside of their natural group, i.e. the family, friends and the firms. Portuguese, Brazilian, Sephardic and Dutch merchants operating from the Republic, Portugal, and other Atlantic areas commonly established commercial webs encompassing several Atlantic Empires - Dutch, Portuguese, Spanish, and even English. To operate their slave trade networks, they chose associates not according to kin, ethnic, religious or cultural background, but rather business interests. Choosing partners outside of the natural groups appears to have been a way not only to reduce risks associated with trafficking, but also to draw capital from different sources into the business, to amalgamate know-how about European and colonial supply and consumption markets, and about the modus operandi through the bureaucratic apparatus of monopolies and their surveilling institutions, either to cooperate and/or circumvent constraints imposed on commercial and financial transactions. ${ }^{86}$ Many of these webs operated their businesses in areas under the control of the monopolies of various European States and/or State-sponsored companies. Individuals connected through these networks carried out transactions between merchants and commercial agents or representatives of different States, commercial companies and 'nations'.

In the eyes of monopoly holders in Lisbon, the Dutch Republic and England, the activities of private merchants and the transactions carried out between them and the officials of the companies in various regions of Western Africa had simultaneously a legal and illegal dimension. The data analysed here is very telling for how private merchant activities and their networks could find ways to circumvent the regulations established by the holders of monopolies on the slave trade, whether they were States or State-sponsored companies. The information discussed here also clearly highlights how the official representatives of the monopoly holders on-the-spot, such as royal or Company officials, not only surveilled the activities of private merchants, but also engaged

86 Cooperation with partners outside of the natural groups as means to reduce risk was not only a strategy employed in the slave trade, but also in other commercial activities developed in the early modern Atlantic world. 
in exchanges deemed legal by the monopoly holders. They also found ways to defy the regulations issued by the monopoly holders in Europe, involving themselves in transactions regarded as 'illegal,' either in their own name, or on behalf of the Company. The latter would often be carried out under the argument that these types of transactions would be beneficial for the monopoly in obtaining a better position than other rival monopolies in the local, regional and international markets. 